\title{
Efficacy of entomopathogenic nematode isolates from Turkey and Kyrgyzstan against the larvae of the mosquito species Culex pipiens L. (Diptera: Culicidae) under laboratory conditions
}

\author{
Seyma Toksoz and Islam Saruhan*
}

\begin{abstract}
Mosquitoes (Diptera: Culicidae) are among the most important of the pests in urban entomology, and they not only disturb people but they are also an important health hazard as they are diseases' vectors. The biological control methods against this pest, which is difficult to fight off, have recently gained importance. A total of five different entomopathogenic nematodes (EPNs), Steinernema feltiae (Aydın isolate), S. carpocapsae (Karadeniz isolate) , and Heterorhabditis bacteriophora (Aydın isolate) isolated from Turkey and S. feltiae (KG3) and H. bacteriophora (KG81) isolated from Kyrgyzstan, were tested against the mosquito species Culex pipiens L. (Diptera: Culicidae) larvae under laboratory conditions. The experimental nematode suspensions were determined as 500, 1000, and $1500 \mathrm{IJs} \mathrm{ml}^{-1}$. The mortality rates in the trial were recorded after $24,48,72,96$, and $120 \mathrm{~h}$. Dead mosquitoes were dissected under a microscope and confirmed to have died by the EPNs. Larval mortality was observed in all EPN species compared to the control group. H. bacteriophora (KG81) and S. carpocapsae isolates were found to be the most effective isolates with 100\% larval mortality. The other isolates were H. bacteriophora (Aydın isolate) (70\%), S. feltiae (KG3) (66.67\%), and the most ineffective isolate S. feltiae (Aydın isolate) (13.3\%).
\end{abstract}

Keywords: Biological control, Entomopathogenic nematodes, Culex pipiens, Larvae, Efficacy, Turkey, Kyrgyzstan

\section{Background}

Pests in urban entomology can be described as insects that affect human health. Insects in urban entomology include cockroaches, ants, termites, houseflies, ticks, insects and mites, bedbugs, lice, and mosquitoes (Robinson 2005).

Mosquitoes are one of the most important urban pests that belong to the Culicidae family of the Nematocera suborder. These pests are found in temperate and tropical regions of the world, except the polar regions (Lancaster and Briers 2008). These pests not only disturb people but they are also an important health hazard as diseases' vectors that spread malaria, dengue, yellow fever, and an important virus of the recent years Zika

\footnotetext{
* Correspondence: isaruhan@omu.edu.tr

Faculty of Agriculture, Department of Plant Protection, Ondokuz Mayis University, Atakum, 55139 Samsun, Turkey
}

(Epstein et al. 1998). There are 112 genera and 3539 species belonging to the Anophelinae and Culicinae subfamilies of the Culicidae family (Harbach 2014). About 50 species of mosquitoes have been identified in Turkey until today (Muslu et al. 2011). Six mosquito species, including Culex pipiens Linnaeus, 1758; C. martini Medschid, 1930; C. deserticola Kirkpatrick, 1924; Aedes caspius Pallas, 1771; Anopheles superpictus Grassi, 1899; and Culiseta longiareolata Macquart, 1838, were found in Antalya; the dominant type was identified as $C$. pipiens (Çetin and Yanıkoğlu 2004).

Control methods against mosquitos' larvae include mechanical, biological, chemical, and an integrated approach where all of the above are used (Alten and Çağlar 1998). The chemical control targeted both larvae and adults, but larvae being the important ones. These pests live in water at all stages, except the adult stage. Today, 
insecticides used as larvicides are of biological origin, but they are very limited in number. Because of the environmental problems caused by insecticides and the effects of non-target organisms, alternative methods of combating these pests are sought. For a sustainable environment, the importance of biological control is increasing among these applications. But unfortunately, the high price of these biological agents at the moment makes it difficult for their broader implementation in the systems of production (Laznik and Trdan 2011).

One of the most successful groups of biological agents for controlling soil insect pests is the entomopathogenic nematodes (EPNs) in the families Steinernematidae and Heterorhabditidae. Nematodes in both families are obligate insect-parasitic organisms that are mutualistically associated with bacteria from the genera Photorhabdus (heterorhabditids) and Xenorhabdus (steinernematids), which are carried within the nematode digestive tracts (Kaya and Gaugler 1993). Nematodes in the infective juvenile (IJ) stages search for an adequate host in the soil and enter the insect host through natural openings (mouth, anus, and spiracles) or through the cuticle. The symbiotic bacteria are then released into the insect hemocoel (Dowds and Peters 2002) at which point the bacteria multiply and produce toxins. The nematodes also contribute to this process, and insect host is killed within $48 \mathrm{~h}$ by septicemia and toxemia (Kaya and Stock 1997; Duchaud et al. 2003). Once nutrients within the insect cadaver are exhausted, progeny nematodes develop into the IJ stages and emerge from the cadaver into the soil to search for another host (Griffin et al. 2005). A total of 86 species of EPN have been identified worldwide (64 belonging to Steinernema, 1 to Neosteinernema, and 21 to Heterorhabditis) (Kepenekci 2014).

The first EPN belonging to the genus Steinernema, detected in Turkey, in soil samples collected from Rize (Turkey), was identified by Özer et al. (1995) as $S$. feltiae. Kepenekci et al. (1999) identified the first nematode in Turkey from the genus Heterorhabditis as $H$. bacteriophora, which was found in an Aelia population (Aelia rostrata Boh.) collected from Ekecik (Aksaray, Turkey) winter quarters. To utilize EPNs in the biological control of pathogens in Turkey, the principal species and hosts, present, should be determined. Although several surveys have been conducted on this subject, there is not yet sufficient information (Kepenekci and Atay 2014).

Narksuwan et al. (2004) tested the EPNs S. carpocapsae (Weiser), S. siamkayai, S. feltiae, $H$. indica, and $H$. bacteriophora against Aedes aegypti (L.), Culex quinquefasciatus, C. gelidus, Anopheles dirus, and A. minimus mosquito species, and all of them were successfully suppressed A. aegypti (L.), C. quinquefasciatus, C. gelidus species (Edmunds et al. 2017). Kepenekci et al. (2014) evaluated the efficacy of $S$. feltiae, S. carpocapsae, $S$. kraussei, and $H$. bacteriophora against Chironomidae family members in their study. They determined that these EPN species could survive for up to $96 \mathrm{~h}$ in water and even after that they could parasitize the larvae of Chironomus plumosus. They caused more than 20\% mortality after $24 \mathrm{~h}$.

In this study, efficacy of five EPN species, isolated from Kyrgyzstan and Turkey, was evaluated against $C$. pipiens larvae collected from the stagnant waters in paddy fields at Samsun (Turkey)'s Bafra province under laboratory conditions.

\section{Materials and methods}

The experiment was carried out at the Entomology Laboratory of Ondokuz Mayıs University (Samsun, Turkey). Five different EPN species were applied to the larvae of $C$. pipiens. The experiment was carried out in six replications and two repetitions.

\section{Nematode sources}

Five Turkish and Kyrgyz EPN isolates, Steinernema feltiae (Aydin isolate) from a vegetable garden in Aydın, $S$. carpocapsae (Karadeniz isolate) from a grassland in Rize, and Heterorhabditis bacteriophora (Aydın isolate) from a peach orchard in Aydın (Turkey), were obtained from the Entomopathogenic Nematode Laboratory of Adnan Menderes University (Aydın, Turkey). S. feltiae (KG3) from an apricot orchard in Talas and $H$. bacteriophora (KG81) from a potato field in Tokmok (Kyrgyzstan) were also obtained from the Nematology and Taxonomy Laboratory of Gaziosmanpaşa University (Tokat, Turkey).

\section{Production of nematodes}

Last instar larvae of the greater wax moth (Galleria mellonella L., Lepidoptera: Pyralidae) was used to culture the nematodes at room temperature $\left(23-24{ }^{\circ} \mathrm{C}\right)$ as described by Kaya and Stock (1997). The new-generation IJs emerged from cadavers were harvested from nematodeinfected larvae which were placed on white traps (White 1927). IJs were collected and rinsed three times in sterile distilled water. Using a tetrapack juice box, each species was kept separately before refrigerating at $10{ }^{\circ} \mathrm{C}$ (Gülcü and Hazir 2012). The harvested IJs were used within 2 weeks after emergence for the experiments.

\section{Production of Culex pipiens}

Third and fourth larval instars of $C$. pipiens were collected from the stagnant water deposits in paddy fields located in the province of Bafra in Samsun (Turkey). The larvae were placed into $10 \times 10 \times 10 \mathrm{~cm}$ containers and 10 larvae were placed in each one. The larvae were fed fishmeal to survive. Identification of mosquitoes brought to the laboratory was carried out by 
Prof. Dr. İzzet AKÇA (Ondokuz Mayıs University, Samsun, Turkey).

\section{Bioassay}

Each EPN species was applied at three concentrations (500, 1000, and $1500 \mathrm{IJs} \mathrm{ml}^{-1}$ ) (approximately 7.5, 15, and $30 \mathrm{IJs} \mathrm{cm}{ }^{2}$ ) at $25{ }^{\circ} \mathrm{C}$ temperatures. One milliliter of distilled water without nematode was used as control. Each plastic container contained moistened filter paper on the bottom. The studies were conducted at the Entomological Laboratory of Ondokuz Mayis Univ. in Samsun. Plastic containers were placed in incubators adjusted at $25 \pm 1{ }^{\circ} \mathrm{C}$ temperatures and $90 \pm$ $5 \%$ R.H. The data for mortality was recorded after 24-, 48-, 72-, 96-, and 120-h intervals. Dead insects were dissected under a stereomicroscope to verify that they were killed by the nematodes.

\section{Statistical analysis}

One-way ANOVA was used to compare mortality rates of $C$. pipiens treatments. Means were compared at the $P<0.05$ level, and Tukey's test was used to separate means. Serial time-mortality data from bioassays were analyzed by probit analysis program (SPSS, Version 21 ) to calculate $50 \%$ lethal concentration $\left(\mathrm{LC}_{50}\right)$ and $90 \%$ lethal concentration $\left(\mathrm{LC}_{90}\right)$.

\section{Results and discussion}

The efficacy of five different EPN isolates and three EPN species [Steinernema feltiae (Aydın isolate), S. carpocapsae (Karadeniz isolate), and Heterorhabditis bacteriophora (Aydın isolate) isolated from Turkey and S. feltiae (KG3) and H. bacteriophora (KG81) from Kyrgyzstan] on $C$. pipiens was determined. When counts were taken $24 \mathrm{~h}$ after inoculation of the EPNs, $H$. bacteriophora (KG81) $1500 \mathrm{ml}^{-1}$ was found to have the highest effect

Table 1 Effect of entomopathogenic nematode isolates on mortality of Culex pipiens

\begin{tabular}{|c|c|c|c|c|c|}
\hline \multirow{2}{*}{$\begin{array}{l}\text { Entomopathogenic } \\
\text { nematodes/ } \\
\text { concentration }\end{array}$} & \multicolumn{5}{|c|}{ Mortality \% (hours) } \\
\hline & 24 & 48 & 72 & 96 & 120 \\
\hline \multicolumn{6}{|l|}{ H.b Aydın } \\
\hline $500^{*}$ & $0.00 \pm 0.00 f$ & $10.00 \pm 4.49 \mathrm{ef}$ & $30.00 \pm 4.49 \mathrm{~cd}$ & $36.67 \pm 3.35 \mathrm{e}$ & $53.33 \pm 4.23 \mathrm{ef}$ \\
\hline 1000 & $0.00 \pm 0.00 f$ & $20.00 \pm 0.00 \mathrm{de}$ & $26.67 \pm 4.23 d$ & $40.00 \pm 0.00 \mathrm{e}$ & $60.00 \pm 0.00 \mathrm{de}$ \\
\hline 1500 & $6.67 \pm 4.23 \mathrm{ef}$ & $26.67 \pm 4.23 \mathrm{~cd}$ & $43.33 \pm 6.17 b$ & $60.00 \pm 0.00 b c$ & $70.00 \pm 4.49 a c$ \\
\hline \multicolumn{6}{|l|}{ H.b KG81 } \\
\hline 500 & $13.33 \pm 6.69 \mathrm{de}$ & $40.00 \pm 7.33 b$ & $90.00 \pm 4.49 a$ & $93.33 \pm 4.23 a$ & $100.00 \pm 0.00 a$ \\
\hline 1000 & $23.33 \pm 3.35 \mathrm{bcd}$ & $30.00 \pm 4.49 \mathrm{bcd}$ & $50.00 \pm 8.60 b$ & $93.33 \pm 4.23 a$ & $100.00 \pm 0.00 a$ \\
\hline 1500 & $43.33 \pm 6.17 a$ & $56.67 \pm 3.35 a$ & $86.67 \pm 6.69 a$ & $96.67 \pm 3.35 a$ & $100.00 \pm 0.00 a$ \\
\hline \multicolumn{6}{|l|}{ S.CK } \\
\hline 500 & $13.33 \pm 4.23 \mathrm{de}$ & $26.67 \pm 4.23 \mathrm{~cd}$ & $43.33 \pm 3.35 b$ & $50.00 \pm 4.49 d$ & $53.33 \pm 4.23 e f$ \\
\hline 1000 & $33.33 \pm 6.69 a b$ & $33.33 \pm 6.69 b c$ & $50.00 \pm 4.49 b$ & $56.67 \pm 6.17 \mathrm{~cd}$ & $90.00 \pm 6.86 b$ \\
\hline 1500 & $30.00 \pm 4.49 \mathrm{bc}$ & $30.00 \pm 4.49 \mathrm{bcd}$ & $50.00 \pm 4.49 b$ & $100.00 \pm 0.00 a$ & $100.00 \pm 0.00 a$ \\
\hline \multicolumn{6}{|l|}{ S.f Aydın } \\
\hline 500 & $0.00 \pm 0.00 f$ & $0.00 \pm 0.00 f$ & $0.00 \pm 0.00 \mathrm{e}$ & $13.33 \pm 4.23 f$ & $20.00 \pm 0.00 \mathrm{~g}$ \\
\hline 1000 & $0.00 \pm 0.00 f$ & $3.33 \pm 3.35 f$ & $10.00 \pm 4.49 e$ & $16.67 \pm 3.35 f$ & $20.00 \pm 0.00 \mathrm{~g}$ \\
\hline 1500 & $0.00 \pm 0.00 f$ & $6.67 \pm 4.23 f$ & $6.67 \pm 4.23 e$ & $10.00 \pm 4.49 f$ & $13.33 \pm 4.23 \mathrm{~g}$ \\
\hline \multicolumn{6}{|l|}{ S.f KG3 } \\
\hline 500 & $13.33 \pm 4.23 \mathrm{de}$ & $33.33 \pm 4.23 \mathrm{bc}$ & $40.00 \pm 0.00 \mathrm{bc}$ & $40.00 \pm 0.00 \mathrm{e}$ & $50.00 \pm 4.49 f$ \\
\hline 1000 & $20.00 \pm 0.00 \mathrm{~cd}$ & $30.00 \pm 4.49 \mathrm{bcd}$ & $36.67 \pm 3.35 \mathrm{bcd}$ & $60.00 \pm 0.00 b c$ & $60.00 \pm 0.00 \mathrm{de}$ \\
\hline 1500 & $26.67 \pm 4.23 \mathrm{bc}$ & $26.67 \pm 4.23 \mathrm{~cd}$ & $40.00 \pm 0.00 \mathrm{bc}$ & $66.67 \pm 4.23 b$ & $66.67 \pm 4.23 \mathrm{~cd}$ \\
\hline \multicolumn{6}{|l|}{ Control } \\
\hline 500 & $0.00 \pm 0.00 f$ & $0.00 \pm 0.00 f$ & $0.00 \pm 0.00 \mathrm{e}$ & $0.00 \pm 0.00 \mathrm{~g}$ & $0.00 \pm 0.00 h$ \\
\hline 1000 & $0.00 \pm 0.00 f$ & $0.00 \pm 0.00 f$ & $0.00 \pm 0.00 \mathrm{e}$ & $0.00 \pm 0.00 \mathrm{~g}$ & $0.00 \pm 0.00 \mathrm{~h}$ \\
\hline \multirow[t]{2}{*}{1500} & $0.00 \pm 0.00 f$ & $0.00 \pm 0.00 f$ & $0.00 \pm 0.00 \mathrm{e}$ & $0.00 \pm 0.00 \mathrm{~g}$ & $0.00 \pm 0.00 \mathrm{~h}$ \\
\hline & $F(1.25)=15.50$ & $F(1.25)=17.15$ & $F(1.25)=43.74$ & $F(1.25)=119.94$ & $F(1.25)=154.12$ \\
\hline
\end{tabular}

Values followed by different letters in the same column differ significantly at $P<0.05$ according to Tukey's test

*Steinernema feltiae (Aydın isolate) (S.f Aydın), S. feltiae (S.f KG3), and S. carpocapsae (Karadeniz isolate) (S.c K) and Heterorhabditis bacteriophora (H.b Aydın) and H. bacteriophora (H.b KG81) from Kyrgyzstan 
(43.33\%). The difference was statistically significant when compared to the control and other concentrations, while no deaths were observed in any concentration of the S. feltiae (Aydın isolate) and in the control group. Deaths in other isolates and concentrations were observed at different rates. After $48 \mathrm{~h}$ from inoculation, it was determined that the most effective concentrations and preparations were $H$. bacteriophora (KG81) $1500 \mathrm{ml}^{-1}$ (56.67\%), followed by the same isolates $500 \mathrm{ml}^{-1}$ (40.00\%), S. carpocapsae (Karadeniz isolate) $1000 \mathrm{ml}^{-1}$, and S. feltiae (KG3) $500 \mathrm{ml}^{-1}$ (33.33\%). After $72 \mathrm{~h}$, a mortality rate of up to $90 \%$ was determined. $H$. bacteriophora (KG81) $\left(500 \mathrm{ml}^{-1}\right)$ was found to be the most effective concentration and preparation. Very little efficacy was determined in all the concentrations of $S$. feltiae (Aydin isolate) isolate. The first 100\% mortality rate was recorded $96 \mathrm{~h}$ post treatment at the concentration of $1500 \mathrm{ml}^{-1}$ for $S$. carpocapsae (Karadeniz isolate) isolate which was determined to be the most effective one, followed by 500,1000 , and $1500 \mathrm{ml}^{-1}$ concentrations of the $H$. bacteriophora (KG81), respectively. According to the results obtained by the end of the experiment $(120 \mathrm{~h}), 100 \%$ mortality rate at the concentration of $1500 \mathrm{ml}^{-1}$ for S. carpocapsae (Karadeniz isolate) and for H. bacteriophora (KG81) at concentrations 500, 1000 , and $1500 \mathrm{ml}^{-1}$ was found. This was followed by isolates and a concentration of $1500 \mathrm{ml}^{-1}$ for $\mathrm{H}$. bacteriophora and S. feltiae, respectively. The lowest mortality rate was determined at $500 \mathrm{ml}^{-1}, 1000 \mathrm{ml}^{-1}$ and $1500 \mathrm{ml}^{-1}$ concentrations of S. feltiae (Aydın isolate) isolate. At least $50 \%$ mortality rate was detected in other concentrations and preparations (Table 1 ). In addition, the mortality rates at the $\mathrm{LC}_{50}$ and $\mathrm{LC}_{90}$ values are shown in Table 2.

As a result, the effectiveness of $H$. bacteriophora (KG81), S. feltiae (KG3), S. feltiae (Aydin isolate), S. carpocapsae (Karadeniz isolate), and $H$. bacteriophora (Aydın isolate) species against C. pipiens larvae was determined, even if at different rates. Especially after $120 \mathrm{~h}, 100 \%$ mortality rates were recorded.

Chaudhary et al. (2017) found that S. kraussie and $H$. bacteriophora were the most effective EPNs between 20 and $30{ }^{\circ} \mathrm{C}$ in a study on the mortality of $A$. aegypti in two different concentrations and three different temperature environments. At $100 \mathrm{IJs}$, concentration of S. kraussie and A. aegypti was found to have $100 \%$ mortality at 48 and 96 h. H. bacteriophora was found to have $100 \%$ mortality rate at $30{ }^{\circ} \mathrm{C}$ with $100 \mathrm{IJs}$ concentration after $96 \mathrm{~h}$. In the present study, the KG81 isolate caused 93.33-96.67\% death after 96 h. Oğuzoğlu and Özer (2007) recorded low mortality rate of S. feltiae (Karadeniz isolate) and one isolate belonging to $H$. bacteriophora, collected from Turkey, on $A$. aegypti which agrees with the obtained results on $C$. pipiens. In another study,
Table $2 \mathrm{LC}_{50}$ and $\mathrm{LC}_{90}$ for Culex pipiens treated with entomopathogenic nematode isolates

\begin{tabular}{llll}
\hline Entomopathogenic nematodes & Concentration & $\mathrm{LC}_{50}$ & $\mathrm{LC}_{90}$ \\
\hline Heterorhabditis bacteriophora (KG81) & 500 & 3.22 & 4.35 \\
& 1000 & 3.47 & 5.61 \\
H. bacteriophora (Aydın isolate) & 1500 & 2.20 & 4.52 \\
& 500 & 5.15 & 7.13 \\
& 1000 & 5.15 & 7.46 \\
Steinernema feltiae (KG3) & 1500 & 4.33 & 6.46 \\
& 500 & 3.47 & 5.61 \\
S. feltiae (Aydın isolate) & 1000 & 4.44 & 7.20 \\
& 1500 & 4.23 & 6.90 \\
& 500 & 5.78 & 6.68 \\
S. carpocapsae (Karadeniz isolate) & 500 & 6.77 & 9.26 \\
& 1000 & 8.47 & 12.28 \\
& 1500 & 4.60 & 7.30 \\
& 1500 & 4.27 & 7.97 \\
& & 3.30 & 5.35 \\
\hline
\end{tabular}

Peschiutta et al. (2014) analyzed the effectiveness of $H$. bacteriophora on $A$. aegypti and found a mortality rate of up to $84 \%$. Obtained data of Kyrgyzstan and Aydın isolates of H. bacteriophora was effective on C. pipiens.

Cagnolo and Almirón (2010) tested six different concentrations of S. rarum (OLI strain) against the larvae of C. apicinus and recorded that the mortality rate increased as the dose increases. They recorded a $75 \%$ mortality rate at a $400: 1$ dose at $25^{\circ} \mathrm{C}$. Pandii et al. (2008) tested S. carpocapsae and H. indica (local Thai strain) against $C$. gelidus. S. carpocapsae showed more effectiveness than $H$. indica. In the present study, 100\% mortality rate for S. carpocapsae (Karadeniz isolate) was recorded, especially after 96 and $120 \mathrm{~h}$.

In a study evaluating the efficacy of $H$. bacteriophora, $H$. indica, S. carpocapsae, and S. feltiae on C. quinquefasciatus, $H$. bacteriophora and $H$. indica were successfully inhibited to C. quinquefasciatus, while S. carpocapsae and S. feltiae showed low mortality rate (Zohdy et al. 2013). In the present study, S. feltiae showed low activity against $C$. pipiens, whereas $H$. bacteriophora had the highest effect.

\section{Conclusion}

Culex pipiens is a well-known species among the mosquitoes found in Turkey. Entomopathogenic nematodes (EPNs) are among the alternative methods to chemical pesticides that give hopeful results in mosquito control. In recent years, studies regarding these have gained speed around the world as well as in Turkey. The EPNs have been shown to be a fairly good alternative method for controlling $C$. pipiens. Future field trials are needed to demonstrate their effectiveness under natural conditions. 


\section{Acknowledgements}

We are grateful to Prof. Dr. Selçuk Hazır (Adnan Menderes Univ., Fac. of Arts and Sciences, Dept. of Biology, Aydın-Turkey) who supplied the Turkey isolates of EPNs and Prof. Dr. Illker Kepenekci (Gaziosmanpaşa Univ., Fac. of Agriculture, Dept. of Plant Protection, Tokat, Turkey) who supplied the Kyrgyzstan isolates of EPNs.

\section{Funding}

No funding

\section{Availability of data and materials}

All data are available at the end of the article, and the materials used in this work are of high quality and grade.

\section{Authors' contributions}

ST and IS designed the study, supervised the work, and wrote the manuscript with input from all authors. ST and IS carried out the experiments. IS analyzed the data. Both authors read and approved the final manuscript.

\section{Ethics approval and consent to participate}

Not applicable

\section{Consent for publication}

Not applicable

\section{Competing interests}

The authors declare that they have no competing interests.

\section{Publisher's Note}

Springer Nature remains neutral with regard to jurisdictional claims in published maps and institutional affiliations.

Received: 6 July 2018 Accepted: 12 October 2018

\section{Published online: 23 October 2018}

\section{References}

Alten S B, Çağlar S S (1998) Vektor ekolojisi ve mucadelesi (sıtma vektorunun biyo-ekolojisi mucadele organizasyonu ve yontemleri). Turkish Ministry of Health Bizim Buro Ankara, (in Turkish), 242 p

Cagnolo SR, Almirón WR (2010) Capacity of the terrestrial entomopathogenic nematode Steinernema rarum (Rhabditida: Steinernematidae) to parasite Culex apicinus larvae (Diptera: Culicidae). Rev Soc Entomol Argentina 69(1-2): $141-145$

Çetin H, Yanıkoğlu A (2004) Antalya kentinde bulunan Sivrisinek (Diptera: Culicidae) türleri, üreme alanları ve baskın tür Culex pipiens L.'in bazı özellikleri Mosquito (Diptera: Culicidae) species, their breeding sites and some biological aspects of dominant species Culex pipiens L. in Antalya, Turkey. Turkish J Entomol 28(4):283-294

Chaudhary MZ, Majeed S, Tayyib M, Javed N, Farzand A, Moosa A, Shehzad M, Mushtaq F (2017) Antagonistic potential of Steinernema kraussei and Heterorhabditis bacteriophora against dengue fever mosquito Aedes aegypti. J Entomol Zool Stud 5(5):865-869

Dowds BCA, Peters A (2002) Virulence mechanisms. In: Gaugler, R. (Ed.), Entomopathogenic Nematology. CABI Publishing, Oxon, UK, pp 79-98

Duchaud E, Rusniok C, Frangeul L, Buchrieser C, Givaudan A, Taourit S, Dassa E (2003) The genome sequence of the entomopathogenic bacterium Photorhabdus luminescens. Nat Biotechnol 21(11):1307

Edmunds CV, Wilding CS, Rae R (2017) Susceptibility of Chironomus plumosus larvae (Diptera: Chironomidae) to entomopathogenic nematodes (Rhabditida: Steinernematidae and Heterorhabditidae): potential for control. Eur J Entomol 114:526-532

Epstein PR, Diaz HF, Elias S, Grabherr G, Graham NE, Martens WJ, Susskind J (1998) Biological and physical signs of climate change: focus on mosquitoborne diseases. Bull Am Meteorol Soc 79(3):409-417

Griffin CT, Boemare NE, Lewis EE (2005) In: Grewal PS, Ehlers RU, Shapiro-llan DI (eds) Biology and behaviour. In: Nematodes as biocontrol agents. CABI Publishing, Wallingford, pp 47-59

Gülcü B, Hazir S (2012) An alternative storage method for entomopathogenic nematodes. Turkish Journal of Zoology 36(4):562-565

Harbach R E (2014) Mosquito taxonomic inventory. ht tp. Mosquito-taxonomicinventory. Info/valid-species-list (Accessed 17 May 2018)

Kaya HK, Gaugler R (1993) Entomopathogenic nematodes. Annu Rev Ent 38:181-206
Kaya HK, Stock SP (1997) Techniques in insect nematology. In: Lacey L (ed) Manual of techniques in insect pathology. Academic Press, San Diego, pp 281-324

Kepenekci I (2014) Entomopathogenic nematodes (Steinernematidae, Heterorhabditidae: Rhabditida) of Turkey. Pak J Nematol 32(1):59-65

Kepenekci I, Atay T (2014) Evaluation of aqueous suspension and entomopathogenic nematodes infected cadaver applications against the great spruce bark beetle Dendroctonus micans (Kugelann),(Coleoptera: Scolytidae). Egypt J Biol Pest Contr 24(2):335

Kepenekci I, Babaroğlu N E, Öztürk G, S Halıcı (1999) Türkiye için yeni bir Entomopatojen nematod Heterorhabditis bacteriophora Poinar 1976 (Rhabditida: Heterorhabditidae). 4. Biyolojik Mücadele Kongresi, Adana, 587-596

Kepenekci I, Tülek A, Erdoğuş D, Evlice E, Toktay H, Devran Z, Hazır S (2014) Türkiye Ayrıntılı Nematoloji Bibliyografyası (1934-2014), Nematoloji'de 80 yıl. ISBN: 978-605-4627-63-9, Siyasal Kitabevi, 444

Lancaster J, Briers R A (Eds.) (2008) Aquatic Insects: Challenges to Populations: Proceedings of the Royal Entomological Society's 24th Symposium. CABI. 332

Laznik Ž, Trdan S (2011) Entomopathogenic nematodes (Nematoda: Rhabditida) in Slovenia: from tabula rasa to implementation into crop production systems. In: PERVEEN F (ed) Insecticides - advances in integrated pest management. InTech, Rijeka, pp 627-656

Muslu H, Özgür T, Özbilgin A (2011) Evaluation of mosquito species (Diptera: Culicidae) identified in Manisa province according to their breeding sites and seasonal differences. Türkiye Parazitolojii Dergisi 35(2):100

Narksuwan M, Rojanawatsirivet C, Buafeungklin A (2004) Biological control of mosquitoes larvae by using entomopathogenic nematodes. Disease Control J 30:158-166

Oğuzoğlu I, Özer N (2007) Bioassays of entomopathogen nematode Steinernema feltiae all type (Rhabditida: Steinernematidae) and Heterorhabditis bacteriophora Tur-H2 (Rhabditida: Heterorhabditidae). Hacettepe J Biol Chem 35(1):39-44

Özer N, Keskin N, Kırbaş Z (1995) Occurrence of entomopathogenic nematodes (Steinernematidae: Heterorhabditidae) in Turkey. Nematologica 41:639-640

Pandii W, Maharmart S, Boonchuen S, Silapanuntakul S, Somsook V (2008) Efficacy of entomopathogenic nematodes (Nematoda: Rhabditida) against Culex gelidus (Diptera: Culicidae) larvae. J Vect Borne Dis 5:24-35

Peschiutta ML, Cagnolo SR, Almirón WR (2014) Susceptibilidad de larvas de Aedes aegypti (Linnaeus)(Diptera: Culicidae) al nematodo entomopatógeno Heterorhabditis bacteriophora (Poinar)(Rhabditida: Heterorhabditidae). Rev Soc Entomol Argentina 73(3-4):99-108

Robinson WH (2005) Urban insects and arachnids: a handbook of urban entomology. Cambridge University Press, UK, 490 p

White GF (1927) A method for obtaining infective nematode larvae from cultures. Science 66:302-303

Zohdy N, Shamseldean M, El-Samiee EA, Hamama HM (2013) Efficacy of the Steinernematid and Heterorhabditid nematodes for controlling the mosquito, Culex quinquefasciatus Say (Diptera: Culicidae). J Mosquito Res 3(1):33-44

\section{Submit your manuscript to a SpringerOpen ${ }^{\circ}$ journal and benefit from:}

- Convenient online submission

- Rigorous peer review

- Open access: articles freely available online

- High visibility within the field

- Retaining the copyright to your article

Submit your next manuscript at $>$ springeropen.com 